\title{
Factors related to first dose hypotensive effect of captopril: prediction and treatment
}

\author{
G P HODSMAN，C G ISLES，G D MURRAY，T P USHERWOOD，D J WEBB，J I S ROBERTSON
}

\begin{abstract}
The blood pressure response to the first dose of captopril (6.25 $\mathrm{mg}, 12.5 \mathrm{mg}$, or $25 \mathrm{mg}$ ) was measured in 65 treated, severely hypertensive patients. Mean supine blood pressure was $187 / 108 \mathrm{~mm} \mathrm{Hg}$ immediately before captopril was given. Twenty one patients experienced a fall in supine systolic pressure greater than $50 \mathrm{~mm} \mathrm{Hg}$, including five whose pressure fell more than $100 \mathrm{~mm} \mathrm{Hg}$ and two whose pressure fell more than $150 \mathrm{~mm} \mathrm{Hg}$. Six patients developed symptoms of acute hypotension, including dizziness, stupor, dysphasia, and hemiparesis. Percentage reductions in blood pressure were greatest in those with secondary hypertension $(\mathbf{p}<0.05)$, high pretreatment blood pressure $(p<0.05)$, and high concentrations of plasma renin and angiotensin $I I(p<0.01)$. No significant correlation was found between fall in blood pressure and serum sodium concentration, age, renal function, and the dose of captopril given.

A severe first dose effect cannot be consistently predicted in individual patients who have received other antihypertensive drugs for severe hypertension. Such patients should have close medical supervision for at least three hours after the first dose of captopril.
\end{abstract}

\section{Introduction}

When the angiotensin converting enzyme inhibitor captopril is first given there is, within two hours, a fall in arterial pressure that is proportional to the concurrent fall in the plasma concentration of angiotensin II. ${ }^{1}$ In some severely hypertensive patients this initial fall in blood pressure is precipitous. ${ }^{2-5}$ The incidence of this potentially dangerous event is unknown, and insufficient information is available to the clinician to aid in its anticipation and, if necessary, treatment.

We report here a study of the hypotensive effect of the first dose of captopril in 65 consecutive patients admitted for treatment of resistant hypertension.

\section{Patients and methods}

Sixty five severely hypertensive patients, including 39 women, were admitted to hospital for treatment with captopril. All had been extensively investigated previously. No underlying cause for the hypertension was found in 36 patients. The remaining 29 had secondary hypertension: 20 had renal artery stenosis or occlusion and the remainder had other forms of renal disease. At the time of admission 52 patients were receiving a diuretic, and all had received

MRC Blood Pressure Unit, Western Infirmary, Glasgow G11 6NT

G P HODSMAN, MB, MRCP, medical registrar

C G ISLES, BSC, MRCP, senior medical registrar

$T$ P USHERWOOD, BSC, MRCP, medical registrar

D J WEBB, MB, MRCP, medical registrar

J I S ROBERTSON, FRCP, FRSE, consultant physician

Department of Statistics, University of Glasgow

G D MURRAY, PHD, statistician

Correspondence to: Dr G P Hodsman. one in the past. Fifty six patients were receiving a beta-blocker, while 33 were also receiving a third, and 13 a fourth antihypertensive drug. Eight were receiving bethanidine alone to facilitate certain investigative? procedures.

Antihypertensive treatment was stopped on the day of admission, $\frac{\overline{\bar{D}}}{\overline{\mathrm{T}}}$ when 21 patients underwent whole body neutron activation analysis $\mathbb{\Phi}$ for assessment of total body sodium. ${ }^{6}$ On the morning after admission an intravenous cannula was inserted so that corrective measures could ${ }^{\mathscr{S}}$ be started at once in the event of a dangerous fall in blood pressure; $\overrightarrow{0}$ the most severely hypotensive patients were given angiotensin II (Hypertensin; Ciba) made up in $5 \%$ dextrose to a concentration $\vec{\omega}$ of $1 \mu \mathrm{g} / \mathrm{l}$ and administered by variable speed infusion pump.

Blood pressure was measured with a standard sphygmomanometer after patients had lain supine for 45 minutes, and blood was drawn. for measurement of serum sodium and creatinine concentrations (allo patients), plasma active renin concentration (normal range 10-50\% $\mathrm{mU} / \mathrm{l})\left(55\right.$ patients), ${ }^{8}$ and plasma angiotensin II concentration (normalë range $5-35 \mathrm{pmol} / 1(5-35 \mathrm{pg} / \mathrm{ml})$ ) (34 patients). ${ }^{9}$ Captopril (Capoten; $\infty$ Squibb) was then given by mouth in a dose of $6.25 \mathrm{mg}$ (20 patients), $12.5 \mathrm{mg}$ (21 patients), or $25 \mathrm{mg}$ (24 patients) at the discretion of the N investigator. All subjects remained supine for a further three hours, 은 during which blood pressure was measured at intervals of 10 minutes.

Statistical analyses of blood pressure were all based on the percent- $\vec{N}$ age change in mean arterial pressure-that is, diastolic pressure plus 3 one third of the pulse pressure. All correlations quoted are Spearman's rank correlations. The falls in blood pressure in the group with $\mathcal{}$ essential hypertension and the group with secondary hypertension $\overrightarrow{0}$ were compared using Welch's modification of Student's $t$ test, whicho does not require the assumption of equal variances in the two groups. As well as considering variables individually we used stepwise. regression analysis to assess the relations of several combinations of variables to the percentage fall in blood pressure.

\section{Results}

FIRST DOSE EFFECT

Blood pressures immediately before the first dose of captopril. ranged from $130 / 96$ to $254 / 145 \mathrm{~mm} \mathrm{Hg}$ (mean $187 / 108 \mathrm{~mm} \mathrm{Hg}$ ). Mean plasma active renin concentration was significantly higher in patients with secondary hypertension, but there were no significant. differences in the mean values before captopril of blood pressure or $\frac{}{3}$ serum sodium or creatinine concentration (table I).

TABLE I-Comparison of blood pressure and biochemical data before captopril ino patients with essential and secondary hypertension (values are means $\pm S E M$ )

\begin{tabular}{|c|c|c|}
\hline & Essential & Secondary \\
\hline $\begin{array}{l}\text { Supine blood pressure }(\mathrm{mm} \mathrm{Hg}) \\
\text { Serum sodium }(\mathrm{mmol} / 1) \\
\text { Serum creatinine }(\mu \mathrm{mol} / 1) \\
\text { Plasma active renin }(\mathrm{mU} / 1)\end{array}$ & $\begin{array}{r}180 / 105: 5 / 2 \\
141: 0 \cdot 6 \\
183: 30 \\
59: 20\end{array}$ & $\begin{array}{c}195 / 112 \div 6 / 4 \\
139 \pm 0.9 \\
206+30 \\
349 \\
134 *\end{array}$ \\
\hline
\end{tabular}

${ }^{*} \mathrm{p}<0.05$.

Conversion: SI to traditional units-Sodium: $1 \mathrm{mmol} / 1=1 \mathrm{mEq} / 1$. Creatinine $1 \mu \mathrm{mol} / 1 \simeq 11.3 \mu \mathrm{g} / 100 \mathrm{ml}$.

The reduction in blood pressure in the whole group ranged fromo $12 / 0$ to $174 / 82 \mathrm{~mm} \mathrm{Hg}$, the nadir occurring at a mean of 110 minutes after the first dose of captopril (range 27-330 minutes). The average fall in blood pressure was significantly greater in those with secondary hypertension $(52 / 29 \mathrm{~mm} \mathrm{Hg})$ than in those with essential hypertension $(33 / 18 \mathrm{~mm} \mathrm{Hg})(\mathrm{p}<0.05)$

Twenty one patients experienced a fall in supine systolic pressure greater than $50 \mathrm{~mm} \mathrm{Hg}$, including five whose pressure fell by more than $100 \mathrm{~mm} \mathrm{Hg}$ and two whose pressure fell by more than $150 \mathrm{~mm} \mathrm{Hg} . ?$ While supine six patients developed symptoms related to the acute? 
TABLE II-Blood pressure and biochemical data in five patients who required urgent correction of hypotension by graded infusions of angiotensin II

\begin{tabular}{|c|c|c|c|c|c|c|c|c|}
\hline \multirow{2}{*}{$\begin{array}{l}\text { Case } \\
\text { No }\end{array}$} & \multirow{2}{*}{ Diagnosis } & \multicolumn{2}{|c|}{ Blood pressure $(\mathrm{mm} \mathrm{Hg})$} & \multirow{2}{*}{$\begin{array}{l}\% \text { Change in } \\
\text { mean arterial } \\
\text { pressure }\end{array}$} & \multirow{2}{*}{$\begin{array}{l}\text { Plasma } \\
\text { active renin } \\
(\mathrm{mU} / 1)\end{array}$} & \multirow{2}{*}{$\underset{\substack{\text { Sodium } \\
(\mathrm{mmol} / \mathrm{l})}}{\operatorname{sedum}}$} & \multirow{2}{*}{$\underset{(\mu \mathrm{mol} / \mathrm{l})}{\operatorname{Serum}}$} & \multirow{2}{*}{$\begin{array}{c}\text { Dose of } \\
\text { captopril } \\
\text { (mg) }\end{array}$} \\
\hline & & Basal & Nadir & & & & & \\
\hline $\begin{array}{l}1 \\
2 \\
3 \\
4 \\
5\end{array}$ & $\begin{array}{l}\text { Renal artery occlusion } \\
\text { Renal artery stenosis } \\
\text { Essential hypertension } \\
\text { Renal artery stenosis } \\
\text { Renal artery stenosis }\end{array}$ & $\begin{array}{l}222 / 128 \\
214 / 136 \\
144 / 102 \\
250 / 112 \\
186 / 120\end{array}$ & $\begin{array}{r}48 / 44 \\
76 / 58 \\
60 / 40 \\
90 / 58 \\
110 / 50\end{array}$ & $\begin{array}{l}72 \\
60 \\
60 \\
57 \\
51\end{array}$ & $\begin{array}{r}575 \\
884 \\
150 \\
2756 \\
2318\end{array}$ & $\begin{array}{l}137 \\
136 \\
139 \\
122 \\
132\end{array}$ & $\begin{array}{r}109 \\
119 \\
141 \\
87 \\
209\end{array}$ & $\begin{array}{r}6 \cdot 25 \\
6 \cdot 25 \\
6 \cdot 25 \\
25 \\
6 \cdot 25\end{array}$ \\
\hline
\end{tabular}

Conversion: SI to traditional units-Sodium: $1 \mathrm{mmol} / 1=1 \mathrm{mEq} / 1$. Creatinine: $1 \mu \mathrm{mol} / 1 \simeq 11 \cdot 3 \mu \mathrm{g} / 100 \mathrm{ml}$.

hypotension, including dizziness, dysphasia, hemiparesis, drowsiness, and stupor. One patient developed electrocardiographic changes of acute myocardial ischaemia. Hypotension was corrected promptly by infusion of angiotensin II in five patients and more gradually by giving $0.9 \%$ saline in one (table II).

\section{CASE REPORTS}

Case 1-The figure shows serial measurements of blood pressure in this 67 year old woman with renal artery occlusion. A combination of atenolol and frusemide had failed to control blood pressure adequately. Immediately before captopril was given plasma active renin concentration was $575 \mathrm{mU} / \mathrm{l}$, serum sodium concentration $137 \mathrm{mmol} / \mathrm{l}$, and serum creatinine concentration $136 \mu \mathrm{mol} / \mathrm{l}(1.54 \mathrm{mg} / 100 \mathrm{ml})$. Her blood pressure started to fall shortly after an oral dose of $6.25 \mathrm{mg}$ captopril and reached a nadir of $48 / 44 \mathrm{~mm} \mathrm{Hg}$ after 27 minutes. She became profoundly drowsy until blood pressure was restored by an infusion of angiotensin $\mathrm{II}^{9}(2 \mathrm{ng} / \mathrm{kg} / \mathrm{min})$, which was continued for further two hours. An infusion of 1.5 litre $0.9 \%$ saline was given over the next 24 hours, when a further $6.25 \mathrm{mg}$ captopril was given. Blood pressure fell on this occasion from $230 / 126$ to $156 / 80 \mathrm{~mm} \mathrm{Hg}$ at one hour, but she developed no symptoms of hypotension. Blood pressure six months later was only moderately well controlled at $200 / 90 \mathrm{~mm} \mathrm{Hg}$ with a combination of captopril $100 \mathrm{mg}$, frusemide $160 \mathrm{mg}$, and metoprolol $50 \mathrm{mg}$ daily.

Case 6-This 55 year old man with essential hypertension had previously been receiving bendrofluazide, timolol, and hydralazine, but blood pressure had remained inadequately controlled. He had intermittent claudication and bilateral carotid artery bruits, though he had had no previous symptoms of cerebral ischaemia. All treatment was stopped on the day before captopril was given. Immediately before an oral dose of $25 \mathrm{mg}$ captopril supine blood pressure was 206/132 $\mathrm{mm} \mathrm{Hg}$, plasma active renin concentration was $71 \mathrm{mU} / 1$, serum sodium concentration was $140 \mathrm{mmol}(\mathrm{mEq}) / 1$, and serum creatinine concentration was $100 \mu \mathrm{mol} / 1(1.13 \mathrm{mg} / 100 \mathrm{ml})$. On administration of captopril blood pressure fell progressively and reached a nadir of $130 / 88 \mathrm{~mm} \mathrm{Hg}$ after 120 minutes. He then became dysphasic with loss of power in his left arm. An infusion of 1 litre $0.9 \%$ saline was given over 120 minutes when blood pressure had returned to $186 /$

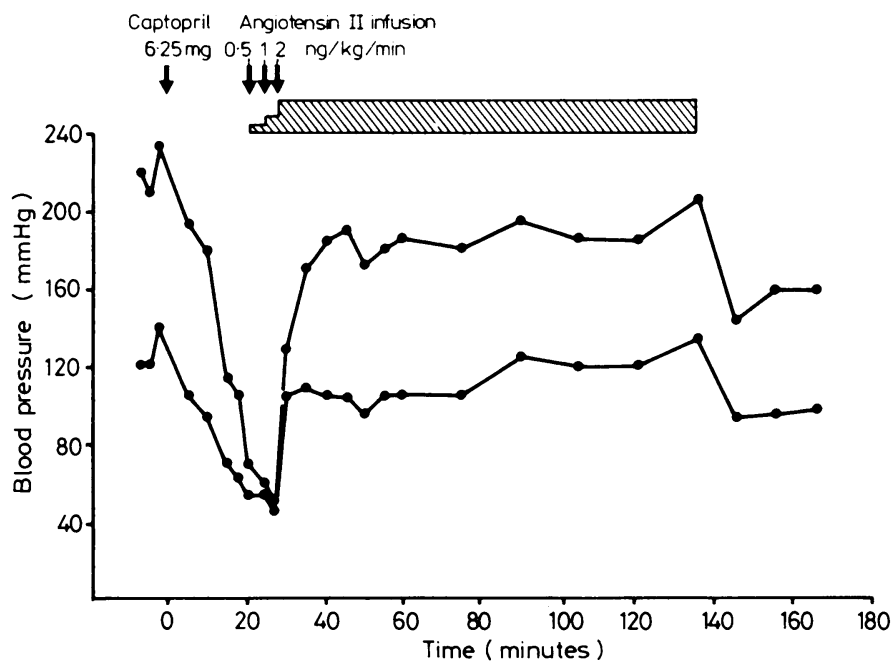

Blood pressure in a 67 year old woman (case 1) after oral captopril $6.25 \mathrm{mg}$. Profound hypotension was immediately corrected by graded infusion of angiotensin II.
$96 \mathrm{~mm} \mathrm{Hg}$. After 24 hours his neurological signs had resolved. Cerebral dysfunction was possibly due to reduced perfusion pressure across stenosed carotid arteries, and treatment with captopril was suspended pending further investigation.

\section{FACTORS CORRELATED WITH FIRST DOSE EFFECT}

Positive correlations (table III) were observed between the percentage fall in blood pressure after the first dose of captopril and pretreatment values of both plasma active renin and angiotensin II concentrations $(p<0.01)$. Patients with a higher basal pressure were likely to have a greater percentage fall in pressure $(p<0.05)$, as were those with secondary hypertension $(p<0.05)$. There was a positive

TABLE III-Spearman rank correlations comparing various factors with percentage change in mean arterial pressure after first dose of captopril

\begin{tabular}{lcccc}
\hline & \multicolumn{2}{c}{ Patients with: } & & \\
\cline { 2 - 3 } & $\begin{array}{c}\text { Essential } \\
\text { hypertension }\end{array}$ & $\begin{array}{c}\text { Secondary } \\
\text { hypertension }\end{array}$ & patients & $\mathrm{n}$ \\
\hline Plasma renin & 0.315 & $0.592^{* *}$ & $0.466^{* *}$ & 55 \\
Plasma angiotensin II & $0.563^{*}$ & 0.454 & $0.519^{* *}$ & 34 \\
Basal blood pressure & 0.170 & 0.322 & $0.253^{*}$ & 65 \\
Serum sodium & 0.097 & -0.242 & -0.060 & 65 \\
Total body sodium & -0.301 & -0.055 & -0.212 & 22 \\
Age & -0.015 & $0.396^{*}$ & 0.197 & 65 \\
Serum creatinine & 0.218 & -0.107 & 0.083 & 65 \\
Diuretic dose & -0.269 & $0.534^{* *}$ & 0.121 & 65 \\
\hline
\end{tabular}

${ }^{*} \mathrm{p}<0.05 ;{ }^{* *} \mathrm{p}<0.01$

correlation between the percentage fall in blood pressure and the dose of diuretic in those with secondary hypertension $(p<0.01)$ but not in those with essential hypertension. There were negative correlations between the percentage fall in blood pressure and both serum sodium concentration and total body sodium, but these were not significant. Age and renal function did not appear to influence the fall in pressure, which was also independent of the dose of captopril given.

Correlations between some physiologically related variables were also examined. There was a significant negative correlation of serum sodium concentration with plasma renin concentration $(r=-0.447$, $\mathrm{p}<0.001)$ but not with plasma angiotensin II $(\mathrm{r}=-0.247)$, total body sodium $(r=0.184)$, serum creatinine concentration $(r=0.081)$, or the dose of diuretic given as previous treatment. Plasma renin concentration correlated significantly with plasma angiotensin II concentration $(r=0.79, p<0.01)$ but not with total body sodium $(r=0.052)$ or serum creatinine concentration $(r=0 \cdot 248)$.

Testing different combinations of measurements against the percentage fall in blood pressure did not show any increase in the ability of individual measurements to predict the fall.

\section{Discussion}

When captopril is first given an acute and highly variable fall in blood pressure occurs which may be very different from the ultimate reduction in blood pressure achieved with long term administration. ${ }^{1}$ The magnitude of the acute fall is closely related both to the initial plasma concentrations of renin and angiotensin II and to the concomitant reduction of circulating angiotensin II concentrations. ${ }^{10-12}$ Patients with renovascular hypertension often sustain greater acute falls in blood pressure, associated with a greater increase in plasma renin concentration, than patients with essential hypertension. ${ }^{13} 14$ Removal of the 
direct vasoconstrictor effect of angiotensin II is probably a major, if not necessarily the sole, ${ }^{71}$ factor in the reduction of blood pressure in the first few hours after inhibition of converting enzyme.

A significant negative correlation between serum sodium and plasma renin concentrations has previously been shown in treated and untreated hypertensive patients and in cardiac failure. ${ }^{16-18}$ Our results thus confirm the generally agreed relations between sodium, renin, and angiotensin II, although these may be modified by the effects of previous hypotensive treatment. Interestingly, however, in this series serum sodium concentration was not significantly correlated with the fall in blood pressure after captopril. The preceding dose of diuretic was significantly related to the fall in blood pressure in patients with secondary hypertension but not in those with essential hypertension. Greater falls in blood pressure occurred in those patients with secondary hypertension and, as is the case with most hypotensive drugs, in those in whom initial pressures were highest. Renal function was not correlated with the fall in blood pressure.

We consider that the effect of the first dose carries a considerable risk in severely hypertensive patients, who are particularly vulnerable to sudden reductions in cerebral perfusion pressure, with the dangers of boundary zone cerebral infarction. ${ }^{19}{ }^{20}$ In this study $8 \%$ of patients sustained an acute reduction of mean arterial pressure in excess of $50 \%$ within two hours of receiving captopril. Sudden suppression of the formation of angiotensin II is probably the most important factor, though other processes may also play a part. Possibly, in addition to arterial dilatation, venodilation and a fall in right atrial pressure may contribute to sudden circulatory collapse in patients with pre-existing volume depletion and poor cardiac reserve.

Unfortunately, our analysis shows that a severe first dose effect cannot be predicted consistently in individual patients. Nevertheless, the present findings suggest that caution should be observed particularly in patients with secondary hypertension, especially if they are already taking diuretics; patients with very high blood pressure; and patients with low or low normal serum sodium. concentrations. If the pretreatment plasma renin or angi tensin JI concentration is known greater precision of prediction is possible, with a high concentration indicating high risk.

As no single test or combination of tests in this study identified all patients at risk our policy is for every patient to receive close medical supervision for at least three hours after the first dose of captopril; during this time the patient remains supine and blood pressure is checked at 10 minute intervals.

In the event of a profound fall in blood pressure we consider that the most appropriate and effective treatment is to restore immediately the substance whose loss led to the reduction in pressure. Thus we have found that graded infusion of angiotensin II (starting dose $0.5 \mathrm{ng} / \mathrm{kg} / \mathrm{min}$, range $0.5-8 \mathrm{ng} / \mathrm{kg} / \mathrm{min}$ ) is fully effective in immediately restoring and maintaining blood pressure. Care must be taken not to give an excessive dose and so raise blood pressure too far. By comparison, rapid infusion of $0.9 \%$ saline is a less effective and less prompt method of restoring blood pressure; moreover, it might prove dangerous in some patients with impaired cardiac function.

Controlled volume repletion with saline before administration of captopril should in theory reduce the risk of profound hypotension, as it will also reduce plasma renin and angiotensin II concentrations. It is, however, impractical to give an infusion to all patients to whom captopril is to be given, and patients at special risk cannot be consistently identified. Stopping diuretic treatment before captopril is given may also reduce the risk of hypotension, but care should be observed in some patients with very high blood pressure or borderline cardiac function.

After a profound fall in blood pressure has been corrected with an infusion of angiotensin II our usual policy is to give at least 1 litre $0.9 \%$ saline over 24 hours before repeating the test dose of captopril. By infusing saline slowly we have not provoked cardiac failure. One patient required 41 saline over four consecu- tive days to prevent excessive reduction in blood pressure afte each daily dose of captopril.

In this study the use of lower doses of captopril $(6 \cdot 25 \mathrm{mg} \$$ conferred no protective effect. Smaller incremental dosag£ increases in the range $1-5 \mathrm{mg}$ should, however, be explored i more detail as an approach to avoiding sudden, virtually complete suppression of generation of angiotensin II with its attendan fall in blood pressure. A severe first dose effect cannot be consistently predicted in individual patients who have receive other antihypertensive drugs for severe hypertension. Such: patients should have close medical supervision for at leas three hours after the first dose of captopril.

\section{References}

${ }^{1}$ Atkinson AB, Brown JJ, Cumming AMM, et al. Captopril in renovascula hypertension: long-term use in predicting surgical outcome. $\mathrm{Br}$ Med $\mathbf{5}$

2 Case DB, Atlas SA, Laragh JH, Sealey JE, Sullivan PA, McKinstry DN Clinical experience with blockade of the renin-angiotensin-aldosteron system by an oral converting enzyme inhibitor (SQ 14225, captopril) io hypertensive patients. Prog Cardiovasc Dis 1978;21:195-206.

${ }^{3}$ McGrath BP, Matthews PG, Johnston CI. Acute changes in blooф̆. pressure and vasoactive hormones after captopril in hypertensive patients. Clin Exp Pharmacol Physiol 1980;7:487-91.

4 Atkinson AB, Robertson JIS. Benefits versus risks of captopril therapyడ్ In: Brunner HR, Gross F, eds. Recent advances in hypertension therapy captopril. Amsterdam, Oxford, Princeton: Excerpta Medica, 1981 \% 50-63.

${ }^{5}$ Raine AEG, Ledingham JGG. Clinical experience with captopril in th treatment of severe drug-resistant hypertension. Am $\mathcal{F}$ Cardiol 1982 49:1475-9.

${ }^{6}$ Williams ED, Boddy K, Harvey I, Haywood JK. Calibration and evaluation of a system for total body in vivo activation analysis using $14 \mathrm{Me}$ neutrons. Phys Med Biol 1978;23:405-15.

7 Atkinson AB, Brown JJ, Fraser R, et al. Antagonists and inhibitors of the renin-angiotensin-aldosterone system in the treatment of hypertension:In : Robertson JIS, Pickering GW, eds. The therapeutics of hypertension $\mathcal{C}_{\infty}$ London: Royal Society of Medicine, 1980:29-61. (Internationatw Congress and Symposium Series No 26.)

${ }^{8}$ Millar JA, Leckie BJ, Morton JJ, Jordan J, Tree M. A microassay fo active and total renin concentration in human plasma based on antibody trapping. Clin Chim Acta 1980;101:5-15.

${ }^{9}$ Düsterdieck G, McElwee G. Estimation of angiotensin II concentration in human plasma: some applications to physiological and clinical states
Eur $\mathcal{\nexists}$ Clin Invest $1971 ; 2: 32-5$.

${ }_{10}$ Laragh JH, Case DB, Atlas SA, Sealey JE. Captopril compared with othe $\overrightarrow{\bar{\sigma}}$ antirenin system agents in hypertensive patients: its triphasic effects or blood pressure and its use to identify and treat the renin factor Hypertension 1980;2:586-93.

${ }^{11}$ Morton JJ, Tree M, Casals-Stenzel J. The effect of captopril on blood. pressure and angiotensins I, II and III in sodium depleted dogs problems associated with the measurement of angiotensin II afte problems associated with the measurement of angiotensin II afterition of converting enzyme. Clin Sci $1980 ; 58: 445-50$.
inhihition

12 Atkinson AB, Morton JJ, Brown JJ, et al. Captopril in clinical hyper tension: changes in components of the renin-angiotensin system and in 3 . body composition in relation to fall in blood pressure with a note or measurement of angiotensin II during converting enzyme inhibition $\frac{\mathrm{O}}{3}$ Br Heart $\mathcal{F} 1980 ; 44: 290-6$.

${ }^{13}$ Imai $\mathrm{Y}$, Abe K, Otsuka Y, et al. Exaggerated response of renin secretion to captopril (SQ 14225) in renovascular hypertension. Fpn Heart f 1980 ก
$6: 793-802$.

McGrath BP, Matthews PG, Johnston CI. Use of captopril in the diagnosis of renal hypertension. Aust NZ F Med 1981;11:359-63.

15 Tree M, Morton JJ. Evidence that the acute hypotensive effect of captoprit. in dogs is not wholly explained by a reduction of plasma angiotensin I and its direct vasoconstrictor effect. Clin Sci 1980;59:451-6.

${ }^{16}$ Brown JJ, Davies DL, Lever AF, Robertson JIS. Plasma renin concen $\omega$ tration in human hypertension. Relationship between renin, sodium and potassium. Br Med $\mathcal{F} 1965 ;$ ii:144-8.

17 Brown JJ, Davies DL, Johnson NW, Lever AF, Robertson JIS. Renin relationships in congestive heart failure, treated and untreated. $A m \stackrel{S}{S}$ Heart $\mathcal{F} 1970 ; 80: 329-42$.

18 Levine TB, Franciosa JA, Urobel T, Cohn JN. Hyponatraemia as a marker for high renin heart failure. Br Heart $\mathcal{F}$ 1982;47:161-6.

19 Graham DI, Jones JV. Hypertension and the cerebral circulation with special reference to the pathophysiology of central nervous system complications of treatment. In: Robertson JIS, Pickering GW, eds. $\frac{\sigma}{\sigma}$ The therapeutics of hypertension. London: Royal Society of Medicine, 1980:105-13. (International Congress and Symposium Series No 26.)

${ }^{20}$ Hodsman GP, Robertson JIS, Semple PF, Mackay A. Malignant hyper-O tension and oral contraceptives: four cases, with two due to the $30 \mu \mathrm{g}$ oestrogen pill. Eur Heart $\mathcal{F} 1982 ; 3: 255-9$.

(Accepted 30 December 1982) 